\title{
Needlestick and sharps injuries among nurses at Atatürk university research hospital and their practices after injury
}

\author{
Elif Okşan Çalıkoğlu®, Banu Bedirø, Hilal Betül Akçay®, Ali Gümüş® \\ Department of Public Health, Atatürk University School of Medicine, Erzurum, Turkey
}

DOI: $10.18621 /$ eurj.404827

\begin{abstract}
Objective: Exposure to needlestick and sharps injuries (NSI) is among the major occupational risks of health workers. Yearly 385,000 NSI are reported by health workers. In this study, we aimed to evaluate the frequency of NSI among nurses at Atatürk University Research Hospital together with the elaboration of the utilization of effective preventive measures used for infection control as well as the affecting factors.

Methods: All 562 nurses working at Atatürk University Research Hospital during September-November 2016 were invited to fill a questionnaire with 27 items. Questions were asked about the sociodemographic characteristics, having experienced NSI, usage of protective equipment, and hepatitis B vaccination status. A total of $555(98.7 \%)$ nurses volunteered to participate. Verbal consent was taken from the participants.

Results: Of the participants, 425 (76.6\%) were females, and 130 (23.4\%) were males. Their mean age was $27.5 \pm 7.4$ years. $52.6 \%(n=293)$ of the participants were in the surgical clinics while $47.4 \%(n=262)$ were in the medical clinics. Of the participants, $21.6 \%(\mathrm{n}=120)$ stated that they experienced a needlestick or sharps injury within the last one year. Of those injuries, $16.7 \%(\mathrm{n}=20)$ happened while removing the needle tip from the syringe, $29.2 \%(\mathrm{n}=35)$ while trying to reattach the needle cap, $16.7 \%(\mathrm{n}=20)$ while filling the syringe, and $12.5 \%(\mathrm{n}=15)$ while drawing blood from the patient.

Conclusion: Health workers should be trained on injuries and all other occupational risks with cutting and puncturing tools, and they should be instructed on the use of protective equipment.
\end{abstract}

Keywords: needlestick injuries, sharps injuries, occupational health, nurses

Received: March 12, 2018; Accepted: April 5, 2018; Published Online: April 9, 2018

$\mathrm{E}$ xposure to needlestick and sharps injuries (NSI) is among the major occupational risks of health workers. According to the Centers for Disease Control and Prevention (CDC) estimates, yearly 385,000 NSI are reported by health workers. On the other hand, it has been shown that $50 \%$ or more of the NSI was not reported [1]. There is the particular importance of NSIcontaminatedwith body fluids in the transmission of more than 20 pathogens, especially HIV, Hepatitis $\mathrm{B}$, and Hepatitis $\mathrm{C}$ to health workers [2]. NSI refer to medical or laboratory equipment (needles, shredded intravenous cannulation devices, broken glass fragments, lancets, pipettes or ampules, and injectors) that can cause skin penetration injury when held by hand [3]. According to the International Labor Organization (ILO), the most exposed occupation to needle injuries among health professionals are nurses [4]. The insufficient number of nurses and the intense and long working hours brings many occupational risks that involve members of this group, including

Address for correspondence: Banu Bedir, MD., Atatürk University School of Medicine, Department of Public Health, Erzurum, Turkey E-mail: banubedir89@hotmail.com 
NSI [5]. Injuries with cutting and needling tools are fundamental problems for healthcare workers in the sense of spreading infections [6]. Transmission mainly occurs by percutaneous or the mucosal route. Percutaneous spread happens through deep cuts, cutting with sharp tools, puncturing with needles, burning or peeling, while transmission via mucosal route occurs by contact with the nose, eyes, oral mucosa, blood, or body fluids [7]. The best method to protect health personnel is to prevent their contact with blood [8]. Means of protection from bloodborne infections are compliance with universal precautions, barriers, cleaning of used devices, gloves, and other equipment, as well as waste disposal, immunization, and protective measures after exposure [9]. The Patient and Employee Security Department of the Ministry of Health is valuable from this perspective [10]. Despite the decrease in percutaneous injuries parallel to the preference of disposable medical devices, blood drawing with vacuum tubes, and appropriate disposal of cutting and needling tools, the current rate of NSI remains still high in Turkey [11].

In this study, we aimed to evaluate the frequency of NSI among nurses at Atatürk University Research Hospital together with elaboration of the utilization of effective preventive measures used for infection control as well as the affecting factors.

\section{METHODS}

The population of this descriptive-cross-sectional study was nurses working at Atatürk University Research Hospital. A questionnaire with 27 items was applied to the participants who accepted to join. Items in the questionnaire were: Questions on the sociodemographic characteristics of participants such as age, gender, marital status, department, and duration of work. The second section of the questionnaire consisted of questions on the experience with NSI such as the practice causing injury (drawing venous blood, cannulation, drug administration, etc.), the injuring instruments (needles, lancets, bottles, etc.), usage of protective equipment, and hepatitis B vaccination status. The population under study consisted of 562 nurses. The study was conducted between September-November 2016. Before the study, approval was obtained from Atatürk University
Faculty of Medicine Ethics Committee (decision no. 01 , date 28.01.2016). All nurses in the population were invited to join the study; $555(98.7 \%)$ volunteered to participate. Verbal consent was taken from the participants.

\section{Statistical Analysis}

The SPSS 22.0 for Windows software (SPSS Inc., Chicago, IL, USA) was used for data analysis. Descriptive statistics for all variables were given as n, percentage, mean, and standard deviation (SD). The Chi-square test was used for the bivariate analysis of categorical variables and Student t test or MannWhitney U test for numerical variables. A $p$ - value $<$ 0.05 was accepted as statistically significant.

\section{RESULTS}

A total of 555 nurses (98.7\%), including 425 (76.6\%) females and 130 (23.4\%) males, participated in the survey. Their mean age was $27.5 \pm 7.4$ years.

Table 1. Demographic characteristics of the participants

\begin{tabular}{lc}
\hline Characteristics & $\begin{array}{c}\text { Data } \\
\text { n (\%) }\end{array}$ \\
\hline Age (years) & \\
$17-24$ & $245(44.1 \%)$ \\
$25-29$ & $145(26.1 \%)$ \\
30 and above & $165(29.7 \%)$ \\
Sex & \\
Male & $130(23.4 \%)$ \\
Female & $425(76.6 \%)$ \\
Marital Status & \\
Married & $225(40.5 \%)$ \\
Single & $320(57.7 \%)$ \\
Divorced & $10(1.8 \%)$ \\
Employed Department & \\
Surgical Disciplines & $292(52.6 \%)$ \\
Medical Disciplines & $263(47.4 \%)$ \\
Intensive Care & $355(64.0 \%)$ \\
Laboratory & $30(5.4 \%)$ \\
Outpatients & $60(10.8 \%)$ \\
Emergency Ward & $5(0.9 \%)$ \\
Dialysis & $20(3.6 \%)$ \\
Inpatient Nurse & $85(15.3 \%)$ \\
Years in the Profession & $185(33.3 \%)$ \\
4-6 years & $135(24.3 \%)$ \\
7-9 years & $100(18.0 \%)$ \\
10 years and above & $135(24.3 \%)$ \\
\hline
\end{tabular}




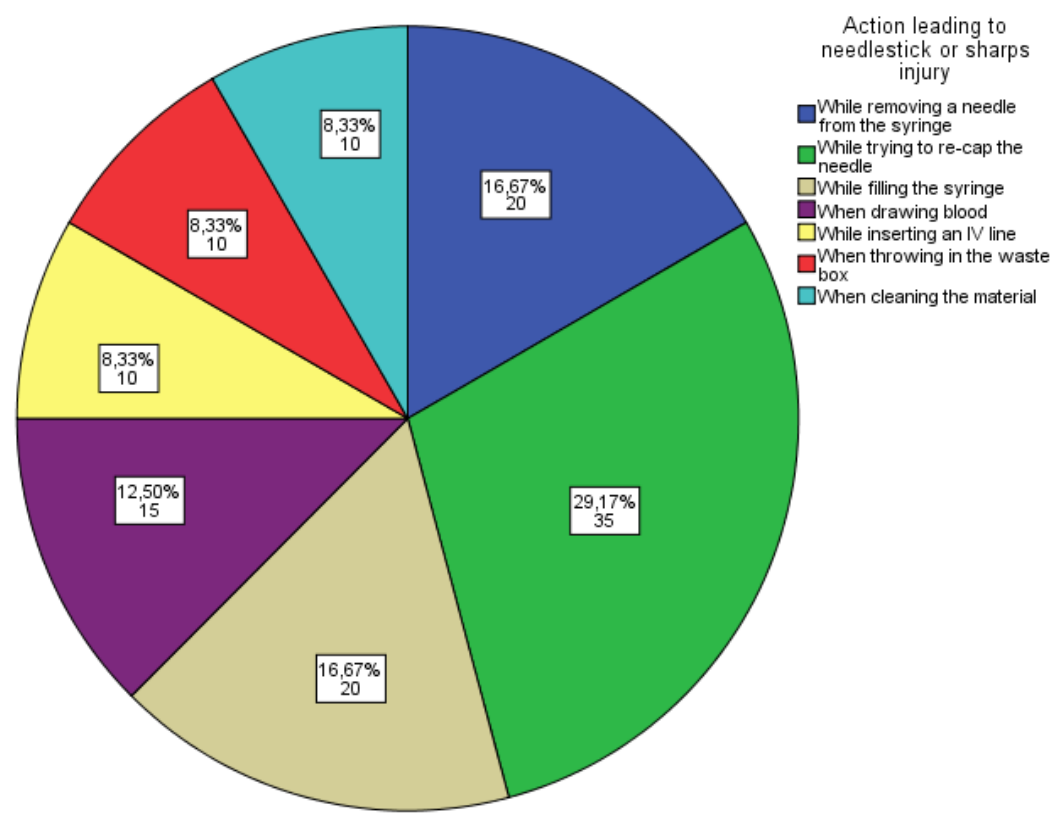

Figure 1. Distribution of actions leading to needlestick and sharps injuries.

$52.6 \%(\mathrm{n}=293)$ of the participants were in the surgical clinics while $47.4 \%(n=262)$ were in the medical clinics. The mean weekly working time of the participants was $40.1 \pm 7.9$ hours. 185 (33.3\%) participants were working in the nursing profession for 0-3 years, $135(24.3 \%)$ for 4-6 years, $100(18.1 \%)$ for $7-9$ years and $135(24.3 \%)$ for more than ten years. Participant characteristics are presented in Table 1. Of the participants, $37.8 \%(\mathrm{n}=210)$ were satisfied with their work and $60.4 \%(n=335)$ indicated that their work was too hard. Only $14.4 \%(n=80)$ of those surveyed stated that they could take a break from work. $60.4 \%$ of those surveyed $(n=335)$ stated that they felt tired when they started work. The proportion of in-service training in the last year was $69.4 \%(n=$ $385)$. Of the surveyed, $13.5 \%(n=75)$ stated that they were afraid of being criticized when reporting a needlestick and sharps injury, while $73.9 \%(n=410)$ said that they did not have such a worry. $42.3 \%(\mathrm{n}=$ 235) of the participants mentioned that employee safety was not a priority the employer, $46.8 \%(\mathrm{n}=$ 260) stated that adequate measures were not taken against their occupational risks in their institutions, and only $35.1 \%(\mathrm{n}=195)$ thought that their institutions provided all equipment to protect them from work accidents. $89 \%(\mathrm{n}=494)$ of the survey participants stated that they used protective equipment during patient interventions.

Of the participants, $21.6 \%(\mathrm{n}=120)$ stated that they experienced a needlestick or sharps injury within the last one year. Of those injuries, $16.7 \%(n=20)$ happened while removing the needle tip from the syringe, $29.2 \%(\mathrm{n}=35)$ while trying to reattach the needle cap, $16.7 \%(\mathrm{n}=20)$ while filling the syringe, and $12.5 \%(\mathrm{n}=15)$ while drawing blood from the patient (Figure 1). Of the surveyed, 26.1\% $(n=145)$ reported having hepatitis B vaccination. Only $48.6 \%$ $(n=260)$ of those surveyed knew that they had to fill out the 'Contaminated Needlesticks, Sharps, or Splash Exposures Follow-up Form' after injury, and 12.5\% (n $=69$ ) of the injured notified their authorities by filling out the follow-up form.

The mean age of those who stated that they had been injured in the last year $(26.6 \pm 6.0$ years $)$ was found to be significantly lower $(t=-2.123 ; p=0.034)$ compared with the uninjured ( $28.3 \pm 8.1$ years). Female nurses $(23.5 \% ; n=100)$ had significantly higher injury rates when compared to males $(11.5 \%$; $\mathrm{n}=15)$ (Chisquare $=9.343 ; p=0.009)$. There was no significant difference between the nurses working in the surgical $(20.5 \% ; n=60)$ or medical wards $(20.9 ; n=55)$ concerning injuries (Chi-square $=1.369 ; \mathrm{p}=0.504$ ). There was a significant difference between injuries with needlestick or sharps of people with different 
weekly working hours. Mean duration of working hours was shorter in those with experience of injury within the last year compared to non-exposed (39.8 \pm 6.5 vs. $40.4 \pm 8.1$ respectively; Mann-Whitney U test; $\mathrm{Z}=-2.567 ; p=0.010)$. There was a significant difference in the injury proportions concerning the duration of work in the profession (Chi-square = 54.302; $p<0.001)$. Participants with 0-3 years, 4-6 years, 7-9 years, and 10 or more years' experience had $24.3 \%(\mathrm{n}=45), 22.2 \%(\mathrm{n}=30), 5.0 \%(\mathrm{n}=5)$, and $25.9 \%(n=35)$ NSI; respectively. Those participants reporting the possibility of giving breaks at work experienced less injury compared to the others (Chisquare $=69.294 ; p<0.001)$. No significant differences in NSI were observed with regard to having received $(23.4 \% ; \mathrm{n}=90)$ or not received $(18.2 \% ; \mathrm{n}=20)$ inservice trainings $($ Chi-square $=1.444 ; \mathrm{p}=0.486)$.

\section{DISCUSSION}

The proportion of participants, who had at least one needlestick or sharps injury within the last year, was $21.6 \%$. A similar study conducted in Muğla revealed a ratio of $42 \%$ [12]. Another study conducted in İzmir showed a proportion of $65.8 \%$ [13], while in a study done in Isparta, this rate was $36.2 \%$ [14]. In the latter investigation, according to the latest injuries remembered, the proportion of NSI was $30.4 \%$. In various studies, it was determined that most of the injuries were caused by injector needles $[15,16]$. In the survey conducted by the $\mathrm{CDC}, 5,000$ percutaneous injuries were identified during the five-year follow-up period, out of which $62 \%$ were due to syringe needles [17].

In our study, the mean age of those who had been injured in the last year was found to be significantly lower than those uninjured. In one research, it was stated that being under the age of 24 , having an experience of four years or less, working in surgical or intensive care units, and working more than 8 hours a day, were factors that increased needlestick an sharps injuries [16]. According to the literature, those working in surgical and intensive care units, having mixed shifts or more extended working hours, nurses with less experience, reloading needles, and those who do not use protective gloves while holding needles are more likely to be injured $[18,19]$.
In our study, although the number of nurses in the surgical units who had NSI was higher than nurses working in medical wards, the difference was not statistically significant. The literature provides ambiguous information on this issue. Among the reasons for the higher number of injuries in the surgical units may be the relatively higher frequency of parenteral applications and procedures in these wards. Many studies have shown that healthcare workers in the emergency and surgical departments had more penetrating puncture injuries than in other units $[2,11,20]$.

The proportion of vaccination against hepatitis B in our study was $73.9 \%$. The probability of infection after percutaneous injuries in the form of needle puncture is $30 \%$ for Hepatitis B 3-4\% for Hepatitis C [21], and $0.3 \%$ for HIV [14]. These rates indicate that percutaneous injuries are a significant risk for Hepatitis B in particular. The practical way of protection from hepatitis $\mathrm{B}$ is vaccination. All healthcare providers should be included in the Hepatitis B vaccination program [22]. However, also the immunity status of post-vaccination persons should continuously be monitored.

It was determined that $51.4 \%$ of the participants in the study were not informed about the form to be filled after a needlestick or sharps injury. Usage of the follow-up form in the event of any injury was found to be $11.7 \%$. In another study conducted in İzmir [13], $13.8 \%$ reported the injury while $34.8 \%$ did not do so, and $5.8 \%$ stated that they were not aware of the regulations about notification. When the reasons for not reporting injury were queried, $15.3 \%$ answered "I did not know how to report" and 7.2\% mentioned, "I had no time for notification". In another study conducted in Mersin, it was determined that $87.3 \%$ of the research group did not report NSI. When the reasons for not reporting the injury were examined, $48.6 \%$ of the employees answered: "I did not know that I had to report," $17 \%$ responded, "I was not worried," and 16\% said, "I did not know the process" [21]. Other studies reported proportions between $32.4 \%$ and $96.2 \%$. When all studies are evaluated together, the most reported reasons for not reporting (in decreasing order) are; negligence, fear of perception, fear of warning, lack of knowledge about the reporting procedures, concerns about privacy, and reluctance [23-25]. 
Fear of being criticized when reporting the injury was $13.5 \%$. In another study conducted in Istanbul, it was stated that especially those who are new to the profession act more timidly in reporting an injury [26]. It was also observed that these people had less knowledge about infectious diseases. Increasing the notification rate is possible by increasing the training of newcomers to the profession [27].

The use of safety devices that cover the needle-tip after hypodermic injection lowers the risk of NSI per HCW by $43.4 \%-100 \%$ compared to conventional devices [28]. The World Health Organization (WHO) recommends the use of safety injection devices and instructs governments to transition to their exclusive use by 2020 [29].

\section{CONCLUSION}

Health workers should be trained on injuries and all other occupational risks with cutting and puncturing tools, and they should be instructed on the use of protective equipment, which must be provided by the employer. Safety-engineered devices should be used for hypodermic injections. Occupational physicians should be assigned to follow up in case of any injury or occupational illness. Not only nurses but all other allied health workers should be provided with for hepatitis B vaccinations and antibody follow-ups, with screening, diagnosis, and treatment support also for other occupational infectious diseases.

\section{Conflict of interest}

The authors disclosed no conflict of interest during the preparation or publication of this manuscript.

\section{Financing}

The authors disclosed that they did not receive any grant during conduction or writing of this study.

\section{REFERENCES}

[1] Centers for Disease Control and Prevention. Workbook for designing, implementing, and evaluating a sharps injury prevention program 2008. Available from:

https://www.cdc.gov/sharpssafety/pdf/sharpsworkbook_2008.pdf.

[2] Omaç M, Eğri M, Karaoğlu L. [Evaluation of occupational needlestick-sharp injuries and status of hepatitis B immunization on nurses working at Malatya province hospitals]. İnönü Üniversitesi Tip Fakültesi Dergisi 2010;17:19-25. [Article in Turkish]

[3] Korkmaz M. [Needlestick and sharp injurıes in health workers] Firat Sağlık Hizmetleri Dergisi 2008;3:17-37. [Article in Turkish]

[4] Elmiyeh B, Whitaker I, James M, Chahal C, Galea A, Alshafi K. Needle-stick injuries in the National Health Service: a culture of silence. J R Soc Med 2004;97:326-7.

[5] Y1ldırım A, Özpulat F. [The knowledge and awareness levels on professional risks of nursing students in a medical vocational high school in Turkey]. Sürekli Tıp Eğitimi Dergisi 2015;24:18-29. [Article in Turkish]

[6] Ilhan MN, Durukan E, Aras E, Türkçüoğlu S, Aygün R. Long working hours increase the risk of sharp and needlestick injury in nurses: the need for new policy implication. J Adv Nurs 2006;56:563-8.

[7] Hatzakis A, Wait S, Bruix J, Buti M, Carballo M, Cavaleri M, et al. The state of hepatitis B and C in Europe: report from the hepatitis B and C summit conference. J Viral Hepat 2011;18 Suppl 1:1-16.

[8] Cardo DM, Bell DM. Bloodborne pathogen transmission in health care workers. Risks and prevention strategies. Infect Dis Clin North Am 1997;11:331-46.

[9] Özvarış ŞB. [Protecting health workers from infections]. Sürekli Tıp Eğitimi Dergisi 1999;9:12. [Article in Turkish].

[10] TC. Sağlık Bakanlığı Sağlık Hizmetleri Genel Müdürlüğü Sağlıkta Kalite ve Akreditasyon Daire Başkanlığı.

[11] Ayranci U, Kosgeroglu N. Needlestick and sharps injuries among nurses in the healthcare sector in a city of western Turkey. J Hosp Infect 2004;58:216-23.

[12] Eğri M, Perlivan E. [Epidemiology of needlestick and sharps injuries in health care workers at Turgut Özal Medical Center]. Sağl1k ve Toplum 2000;10:35-9. [Article in Turkish]

[13] Samancioğlu S, Ünlü D, Durmaz Akyol A. [The evaluation of needlestick and sharp injuries among intensive care nurses]. Anadolu Hemşirelik ve Sağlık Bilimleri Dergisi 2013;16:43-9. [Article in Turkish]

[14] Kişioğlu AN, Öztürk M, Uskun E, Kırbıyık S. [In a medical hospital's health workers incisive and perforating injury epidemiologies and prevention behaviours and attitudes]. Turkiye Klinikleri J Med Sci 2002;22:390-6. [Article in Turkish]

[15] Cheng F, Ford W, Cheng S, Weber M, Kerndt P. Occupational risk of acquiring HIV infection through needlestick injuries. Clin Perform Qual Health Care 1995;3:147-50.

[16] Rakickene J, Barkowska T, Caplinskas S. [Occupational HIV infection. Medical workers and HIV prevention]. Zh Mikrobiol, Epidemiol, Immunobiol 2000;4:73-4. [Article in Russian]

[17] CDC. Sharp injuryprevention program workbook 2008, 2008. Available from: http://www.cdc.gov/Sharpssafety/pdf/sharpsworkbook [18] Salehi AS, Garner P. Occupational injury history and universal precautions awareness: a survey in Kabul hospital staff. BMC Infect Dis 2010;10:19.

[19] Nsubuga FM, Jaakkola MS. Needle stick injuries among nurses in sub-Saharan Africa. Trop Med Int Health 2005;10:773-81.

[20] Shiao J, Guo L, McLaws ML. Estimation of the risk of bloodborne pathogens to health care workers after a needlestick injury in Taiwan. Am J Infect Control 2002;30:15-20.

[21] Altıok M, Kuyurtar F, Karaçorlu S, Ersöz G, Erdoğan S. [Healthcare workers experiences with sharps and needlestick injuries and precautions they took when injuring]. Maltepe Üniversitesi Hemşirelik Bilim ve Sanatı Dergisi 2009;2:70-9.

[22] Türkistanlı E, Şenuzun FE, Karaca BS, San AT, Aydemir G. [The state of the immunization of the health workers who have working in Ege university research hospital]. Ege Tip Dergisi 2000;39:29-32. [Article in Turkish]

[23] Souza-Borges FR, Ribeiro LA, Oliveira LC. Occupational exposures to body fluids and behaviors regarding their prevention and 
post-exposure among medical and nursing students at a Brazilian public university. Rev Inst Med Trop São Paulo 2014;56:157-63.

[24] Prasuna J, Sharma R, Bhatt A, Arazoo A, Painuly D, Butola H, et al. Occurrence and knowledge about needle stick injury in nursing students. J Ayub Med Coll Abbottabad 2015;27:430-3.

[25] Yang YH, Liou SH, Chen CJ, Yang CY, Wang CL, Chen CY, et al. The effectiveness of a training program on reducing needlestick injuries/sharp object injuries among soon graduate vocational nursing school students in southern Taiwan. J Occup Health 2007;49:424-9.

[26] Merih YD, Kocabey MY, Çırpı F, Bolca Z, Celayir AC. [Epidemiology and preventive measurementsof sharps injuries in a state hospital during the last three years]. Zeynep Kamil Tip Bülteni 2009;40:11-5. [Article in Turkish]

[27] Ede G, Kaptan D. Injury experiences and precautions taken by nurses working in pediatric wards towards penetrative/incisive tools. Int J Caring Sci 2016;9:569-78.

[28] Cooke CE, Stephens JM. Clinical, economic, and humanistic burden of needlestick injuries in healthcare workers. Med Devices (Auckl) 2017;10:225-35.

[29] World Health Organization. WHO guideline on the use of safetyengineered syringes for intramuscular, intradermal and subcutaneous injections in health-care settings. Geneva, Switzerland. 2015. 